\title{
Grammatical Terminology for the Teaching of African Languages at Tertiary Level*
}

\author{
C.T. Msimang, Department of African Languages, University of South \\ Africa, Pretoria, Republic of South Africa
}

\begin{abstract}
The article addresses the question of the elaboration and modernisation of African languages to enable them to be used as language media for the teaching of African languages, particularly grammar. Whereas all institutions at tertiary level of education have undergone a paradigm shift from teaching African languages in English and Afrikaans to teaching them in their own medium, the necessary terms to ensure efficiency in this process are lacking. Scholars therefore need to focus on term creation and thereafter standardization of the terminologies. Some flaws in the creation of African terminologies in the past are highlighted and remedies suggested. It is recommended that statutory bodies such as the Council for Higher Education (CHE) or the South African Qualifications Authority (SAQA), or academic bodies such as the African Languages Association of Southern Africa (ALASA) could be entrusted with the task of the standardization of these terminologies.
\end{abstract}

Keywords: AFRICAN LANGUAGES, LANGUAGE MEDIUM, GRAMMATICAL TERMINOLOGY, TERM CREATION, STANDARDIZATION OF TERMINOLOGY, TEACHINGG AT TERTIARY LEVEL.

Opsomming: Grammatiese terminologie vir die onderrig van Afrikatale op tersiêre vlak. Die artikel behandel die vraag oor die uitbouing en modernisering van Afrikatale om hulle in staat te stel om as taalmedia gebruik te word in die onderrig van Afrikatale, veral taalkunde. Waar alle inrigtings op tersiêre opvoedkundige vlak 'n paradigmaverskuiwing ondergaan het vanaf die onderrig van Afrikatale in Engels en Afrikaans na die onderrig daarvan in hul eie medium, ontbreek die nodige terme om doeltreffendheid in hierdie proses te verseker. Geleerdes moet hulle daarom toespits op termskepping en daarna op die standaardisering van die terminologieë. Sommige gebreke in die skepping van die Afrikataalterminologieë in die verlede word belig en regstellings voorgestel. Daar word aanbeveel dat statutêre liggame soos die Raad op Hoër Onderwys (RHO) of die Suid-Afrikaanse Kwalifikasieowerheid (SAKO), of akademiese verenigings soos die Afrikatale-Vereniging van Suider-Afrika (AVSA) met die taak van die standaardisering van hierdie terminologieë toevertrou word.

Keywords: AFRIKATALE, TAALMEDIUM, GRAMMATIKATERMINOLOGIE, TERMSKEPPING, TERMINOLOGIESTANDAARDISERING, ONDERRIG OP TERSIÉRE VLAK.

This paper was delivered at the ALASA Biennial Conference held at the University of South Africa; Pretoria, 6 July 1999. 
The main purpose of this paper is to highlight certain problem areas in coining and developing grammatical terminologies in African languages. This problem is the result of a switch at tertiary education institutions from teaching the grammar of African languages in English or Afrikaans to teaching it through the medium of the African languages themselves. The paper will end up by suggesting ways and means of addressing the problem. As far as possible, examples will be drawn from the Zulu language.

Changing from an established tradition is not always easy. Nonetheless this particular change is welcome and is perhaps long overdue for a number of considerations. Firstly, this transformation is in line with the strong pedagogical view that the best medium in which to teach a person is his/her mother tongue. Therefore, for those students who learn an African language as their first language, the medium of teaching and learning should be that language itself. Secondly, in the South African education system the grammar of African languages at primary and secondary school level is taught in the medium of those languages. It subsequently becomes problematic for those students to change at tertiary level from an African to an English language medium. If that university student is a prospective teacher, he/she would, for instance, be learning Zulu in English to enable him/her to teach it better in Zulu - an anomalous situation.

While there is a consensus of opinion on the advantages of teaching the grammar of an African language in its own medium, there are also many limitations. Firstly, of course, there is the lack of relevant terminologies. Secondly, this approach restricts the number of potential scholars. Once African languages and literatures are in African language media, non-Africans have no access to such studies. The studies become too localised and are thus not exposed to international scholarship and critique. This also limits overseas study opportunities for such scholars. Thirdly, within the Bantu language family itself, it becomes difficult if not impossible to engage in comparative Bantu linguistics or grammatical typology. Correspondences between languages cannot be critically analysed without a bridge language. These, however, must be seen more as challenges than problems.

In an attempt to set the scene for coining grammatical terms in African languages, the approach of Louwrens (1994) will be used as a point of departure. Louwrens considers three broad areas in his approach. The first area comprises terms with an official status. These are the terms found in the fourth edition of the series Terminology and Orthography, 1988-1993, issued by the Department of Education and Training, Pretoria. Separate volumes were published on each of the languages then offered by the Department at different intervals. Whilst these are very important term banks, it should be borne in mind that they provide terminology only up to secondary level. Terms in English (or Afrikaans) introduced at tertiary level will not always have a counterpart in these African language lists. The second area comprises terms coined in a haphazard manner by grammarians who produce language manu- 
als or other treatises in African language media. These terms are coined in order to fill in linguistic gaps where the official source does not provide the desired terms. Finally, there is an area where no terms are available.

The foregoing makes it very clear that language elaboration in African languages is far from adequate. Not only are there gaps, but even the available technical terms lack acceptability which is necessary for standardisation. Without elaboration and standardisation of African language terminologies the teaching of such languages in their own medium can never be effective. This is where official bodies and African language teachers should come in and address the defects and discrepancies. A few thoughts on such defects and discrepancies are apt at this juncture.

Perhaps one should start from the formal to the informal. This takes us back to the Terminology and Orthography series. The first edition of these appeared in 1957 under the auspices of the Department of Native Affairs. Only two publications were issued, one for Zulu and Xhosa and the other for the three Sotho languages. The second edition was published in 1962 under the auspices of the Department of Bantu Education. A separate publication appeared for each language, namely: Zulu, Xhosa, Tswana, Northern Sotho and Southern Sotho. The same Department issued the third edition of this series in 1976. Finally, the Department of Education and Training was responsible for the fourth edition between 1988 and 1993.

In her current research Van Huyssteen (1999) refers to criticism of this series of official terminology lists compiled by various Language Committees which later became Language Boards. Citing Cluver and other authorities, she (Van Huyssteen 1999: 2) states that critics "have questioned the legitimacy of terms listed" in these publications. Such critics "feel that terms in the African languages were coined artificially on legislative demand and were therefore imposed on the speakers". These critics concluded that this resulted in an "exclusive short-lived lexicon" which was unacceptable. They suggested that the creators use terms that already exist in society, thereby making them more acceptable to the users.

While this criticism contains some validity, it is generally short-sighted, biased and subjective. It does not seem to take cognisance of the fact that a statutory linguistic structure is essential for the standardisation of a language - in this case the Department of Education and Training and its Language Committees/Language Boards. The Department only provided enabling statutes and infrastructures. Once the Committees/Boards started functioning, they enjoyed a measure of autonomy and were not subjected to undue pressure from the government. They were staffed by outstanding educationists and social leaders with a recognised standing in the Black community. Although they were condemned by certain ideologists for serving in apartheid structures, their only aim was to help elaborate and standardise their languages which they loved, and they plied this business with enthusiasm, devotion and utmost 
commitment. It is true that they made errors along the way, but their bona fides were always above board.

The process should not be dubbed illegitimate simply because of the intervention by the erstwhile government. Terminologies are accepted or rejected purely on their linguistic impact. Even pioneering lexicographers such as C.M. Doke and B.W. Vilakazi who compiled the English-Zulu/Zulu-English Dictionary before the birth of apartheid (Vilakazi actually died in 1947) furnished a number of unacceptable Zulu equivalents for certain foreign English concepts. A glaring example is their Zulu definition of culture, i.e.. improvement or refinement of mind, manners, etc., by education and training (Oxford Illustrated Dictionary 1962: 196). They translated this term as: Ukukhanya okunjengokwabelungu (Light which resembles that of the white people). This definition is not only unacceptable, it is also misleading and insulting. It is misleading to claim that culture is equivalent to light. "Enlightenment" would have been a better choice. It is insulting to claim that only white people have a culture.

It is somewhat simplistic to demand that the creators of terms in the Terminology and Orthography lists should have consulted various speech communities and used terms that already existed in such communities. This shows ignorance of the fact that term creators were part of those Black speech communities and that they interacted with members of such communities using existing terms. This fact made consultation redundant.

Secondly, this charge does not consider the circumstances under which term creation often happens. A news reader over the radio or on the television can be cited as an example. This person receives the news bulletin in English or Afrikaans, one or two hours before broadcast time. He/She must translate and type out a Zulu, Xhosa, Venda, or Tsonga version and read it timeously. If he/she comes across a term that does not have an equivalent in available dictionaries and terminology lists, he/she must create one on the spot. When therefore will he/she find time to consult?

Thirdly, and perhaps more importantly, this charge fails to take cognisance of the fact that theories which are applied to analyse African data, including the grammars of African languages, are foreign to such data. These are usually imported from Europe or the United States of America. If concepts in such theories are introduced only at tertiary level of education, their counterparts in African languages will not be found in the official terminology lists which cater mainly for primary and secondary education level. In all probability, members of African speech communities at grass roots level shall not have been exposed to such concepts. Under the circumstances, one can hardly.speak of consultation or use of existing terms. Reference has already been made to Louwrens' (1994: unpaginated Preface) categorisation of Northern Sotho terms for which counterparts were coined, English terms for which no Northern Sotho counterparts have been suggested and English terms for which Northern Sotho counterparts do exist. Against this scenario what chances are there for 
the existence of popular counterparts in Northem Sotho, Southern Ndebele; Southern Sotho, Swati, Tsonga, Tswana, Venda, Xhosa or Zulu speech communities of the following grammatical concepts?

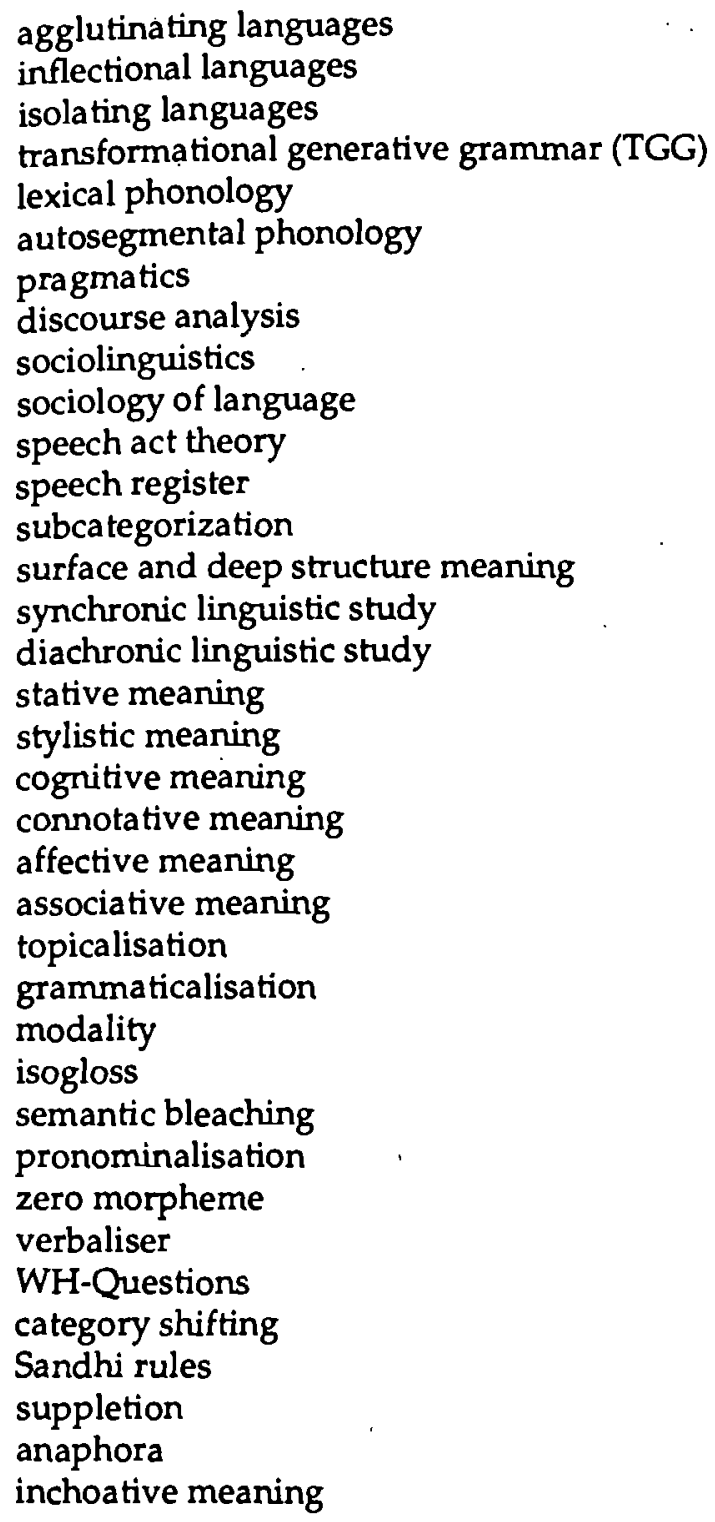

This is but a small sample of linguistic expressions. A more comprehensive linguistic term bank is to be found in David Crystal's book An Encyclopaedic Dictionary of Language and Languages. The 1992 edition of this collection comprises 
2750 entries in a 428 page volume. Yet even this figure is, by Crystal's own admission (on the inside of the cover jacket), not all embracing as he delineates his scope thus: "Linguistic here does not mean technical terminology of linguistic sciences, but language in a more everyday sense."

Obviously, African language counterparts of these and many other grammatical terms shall need to be coined through tutorials and workshops by university communities or by grammarians in their studies and libraries. This then takes us to the informal domain.

Louwrens (1994: unpaginated Preface) has already referred to the dangers of terminographers working in isolation. He states:

It should be emphasised that some of these "new" coinages are already unofficially employed particularly in school manuals which are used for mother-tongue instruction. This obviously results from the pressing need which is experienced by authors of such works for suitable official terms which cover the broad grammatical spectrum ... Unfortunately, grammarians who have in the past been involved in the coining of terms such as these have, in most cases, worked independently of one another, with the result that there is no uniformity and consistency with regard to either the terms which have been decided upon, or the way in which they are applied.

What Louwrens observed in Northern Sotho also occurs in Zulu, and causes confusion. A few examples of literary terms used by the Departments of African Languages at the University of Zululand and the University of South Africa illustrate this point.

English term

\section{University}

of Zululand

suspense

anticlimax

plot

\section{Zulu term}

\section{University of South Africa}

ilukuluku
upholavuthondaba
isakhiwo

The moral lesson from this experience is that independent and individualistic term creation should be followed by standardisation.

The foregoing should not however blind us into thinking that those on Language Committees/Language Boards did not make mistakes. Although they were members of their communities, they did not always recognise the popular terms which had been created spontaneously by these communities and which could have facilitated their task and ensured ready acceptability of the term bank. Since most of these Committee/Board members were language 
purists, they often frowned upon and ultimately rejected the borrowings used by people at grass roots level. This was a serious oversight which had two dire consequences for language elaboration. In the first place, this stultified language modernization. The surest way of killing a language is to maintain its pure form. Secondly, it lead to some distortion of meaning where African language lexemes were used as neologisms (in extended or compounded forms) to express foreign concepts from an English or Afrikaans context.

However, grammarians are not unanimous on the significance of extending the meaning of lexical items so as to create technical terms. For instance, Louwrens (1994: unpaginated Preface) views this in a positive light with regard to Northern Sotho: "A more important reason why it was decided to create terms where Northern Sotho has no equivalents, is because it was felt that even if these new creations were not official, they put the novice who is a mothertongue speaker of Northern Sotho in a better position to conceptualise the semantic content of the English counterpart." While there can be concurred with this view, it must be added that in Zulu at least, this theory has not always been upheld in practice. A few examples will help illustrate this point.

For many years certain Zulu sticklers for language purity refused to 'bastardise" the Zulu language by accepting the adoptive itafula (from Afrikaans tafel) as an equivalent for table. Instead they imposed the word ithala. This completely distorted the meaning of the word ithala, since this piece of furniture is more of a shelf which is suspended from the roof at the back of a Zulu hut, and is used for storing objects, whereas the table is a piece of furiniture with a flat top of wood, marble, etc. and vertical supports, used mainly for laying meals. Eventually common sense prevailed and ithala was discarded and itafula adopted in the modern Zulu term bank.

In grammar, however, there is quite a number of problematic terms. Take indlela, for instance. This word glosses as path, way or road, but in Zulu grammar it is used to denote mood. No stretch of the imagination can show compatibility between these two concepts. One needs to know the significance of mood in English first before one could accept indlela as its Zulu equivalent. Let us consider more examples from Kumalo (1987: 21-22):

English term

Zulu equivalent

dissimilation grammatical tone determiner

inhlukano
izwi lohlelo
isilawuli

Literal meaning of the equivalent

separateness

word/voice of arrangement controller

Coinages created in this manner are normally self-explanatory if they refer to concrete objects, e.g. umtholampilo (clinic), isiqedakoma (cool drink) and isiqedaphunga (deodorant). 


\section{Coinage}

umtholampilo (clinic)

isiqedakoma (cool drink)

isiqedaphunga (deodorant)

\section{Gloss}

-thola $=$ find; impilo $=$ health

i.e. a place where one's health is restored

-qeda $=$ finish $/$ quench; ukoma $=$ thirst

-qeda $=$ finish; iphunga $=($ bad $)$ smell

Where a coinage expresses an abstract notion, publicity especially through media could be the only way to facilitate acceptance of such a term. Indlela has been accepted as an equivalent of mood, for instance, owing to its wide publicity in the school environment.

It is pleasing to note that the Zulu Language Board gradually moved from a puritan standpoint and started accepting adoptives. In the 1993 edition of Zulu Terminology and Orthography one often comes across two Zulu equivalents for a single English term. The one equivalent is invariably an indigenous word and the other an adoptive from English or Afrikaans. Invariably the adoptive becomes more popular, which demonstrates the power of internationalisation over indigenisation:

$\begin{array}{lll}\text { English term } & \text { Zulu indigenous term } & \text { Zulu adoptive } \\ \text { refrigerator } & \text { isiqandisi } & \text { ifriji } \\ \text { radio } & \text { umsakazo } & \text { irediyo } \\ \text { script } & \text { ubhalo } & \text { isikripthi } \\ \text { toy } & \text { isilibaziso sengane } & \text { ithoyi } \\ \text { television } & \text { umabonakude } & \text { ithelevishini } \\ \text { grammar } & \text { uhlelo } & \text { igrama } \\ \text { phonetics } & \text { ubhalojikelele } & \text { ifonethiki }\end{array}$

Khumalo too has become a strong advocate of internationalisation in his later publications.

While the above adoptives give the impression that terms created by the people on the ground are borrowings, this is not necessarily the case. A cursory scanning of the lexical items created by people in road construction, for example, convinces one that these people are highly creative. For instance, they watch the movements of the caterpillar and then name it isixaxa, where the ideophone xaxa glosses as short, staccato forward leap. They also watch the heavy skidding of the rear wheels of a tractor and call this vehicle ugandaganda, where the ideophone ganda glosses as heavy stampeding. It is also interesting how the people on the ground combine borrowing and transliteration to arrive at new adoptives. Take the term bathroom, for example. The official equivalent thereof is igumbi lokuhlambela (igumbi $=$ room/chamber; ukuhlambela $=$ for washing). The Zulus who work in the compounds where 
the chamber is so big that it is called a washing house, simply call it iwashawozi (washa = a borrowing from wash; wozi = a transliteration of house). Other interesting examples are umalaleveva for malaria fever (umalala = the one who sleeps; eveva = trembling) and ithuba-lakho-losizi for tuberculosis (ithuba $=$ time; lakho $=$ of you; losizi = of misery). In both cases (the one who trembles during his/her sleep, and your time of misery) the translation results in an accurate description in Zulu of the consequences of malaria fever and tuberculosis.

This was an attempt at highlighting initiatives that have been made in addressing the challenges of teaching African languages in their own medium. Reference has been made to Zulu examples so as to illustrate ways and means that are often employed to develop terminologies. Unsubstantiated criticism of some of these methods was discussed, while the validity of developments from the ground was acknowledged albeit with certain limitations where foreign theories not always accessible to people on the ground are involved. The need for publication and acceptability of the terms was emphasized as the necessary step towards standardisation. Standardisation at tertiary level, however, could be problematic since there is no overarching linguistic body for all colleges, technikons and especially the universities which enjoy a large measure of autonomy. Could a Quality Promotion Unit of SAUVCA (the South African University Vice-Chancellors Association) undertake such a standardising task particularly for the university membership? Could the necessary task be entrusted to a statutory authority such as PANSALB (the Pan South African Language Board) or a relevant SGB (Standards Generating Body) under the auspices of SAQA (the South African Qualifications Authority), or should this be left to scientific organisations such as ALASA (the African Language Association of Southern Africa)? Consensus on an acceptable choice needs to be sought from all interested role-players.

\section{Bibliography}

Coulsin, J., C.T. Carr, L. Hutchinson, D. Eagle (Eds.). 1962. Oxford Illustrated Dictionary. London: Oxford University Press.

Crystal, D. 1992. An Encyclopaedic Dictionary of Language and Languages. Cambridge: Blackwell.

Department of Education and Training. 1993. Zulu Terminology and Orthography. Pretoria: The Government Printer.

Doke, C.M., D.M. Malcolm, J.M.A. Sikakona and B.W. Vilakazl. 1990. English-Zulu/Zulu-English Dictionary. Johannesburg: Wits University Press

Kumalo, M.B. 1987. Current and Proposed New Terminology in Language Description and Zulu Literature. Educamus 33(4): 21-24, April.

Louwrens, L.J. 1994. Dictionary of Northern Sotho Grammatical Terms. Pretoria: Via Afrika.

Van Huyssteen, L. 1999. Research Methodology for the Testing of the Extent of Acceptability of Zulu Technical (Health) Terms and the Testing of Language Attitudes towards Zulu. Ongoing Ph.D. research. Pretoria: University of South Africa. 